\title{
In Defense of Clinical Autopsy and Its Practice in Cuba
}

\author{
Alfredo D. Espinosa-Brito MD PhD and José Hurtado de Mendoza-Amat MD PhD DrSc
}

\begin{abstract}
There has been a notable decrease in the global practice of clinical autopsy; the rate has fallen to below $10 \%$, even in highincome countries. This is attributed to several causes, including increased costs, overreliance on modern diagnostic techniques, cultural and religious factors, the emergence of new infectious diseases and negative attitudes on the part of doctors, even pathologists. Alternative methods to autopsy in postmortem studies have been developed based on imaging, endoscopy and biopsy (all quite expensive). These methods have been used in developed countries but never as effectively as the classic autopsy for identifying cause of death and potential medical errors.

Although Cuba has also seen a decrease in its autopsy rates, they remain comparatively high. Between 1996 and 2015 , there were 687,689 hospital deaths in Cuba and 381,193 autopsies, $55.4 \%$ of the total. These autopsies have positively affected medical care, training, research, innovation, management and society as a whole. Autopsies are an important tool in the National Health System's quest for safe, quality patient care based on the lessons learned from studying the deceased.
\end{abstract}

KEYWORDS Autopsy, postmortem examination, postmortem diagnosis, quality of care, patient safety, medical error, Cuba

\section{INTRODUCTION}

Despite the valuable information that postmortem examinations can provide, global rates of clinical (nonforensic) autopsy have significantly decreased in recent decades. This is a reflection of a clear trend to reduce their importance.[1] This can be attributed to different factors.

- Scientific/technical: overreliance on modern diagnostic research techniques (imaging, lab analyses, biopsies), based on the assumption that they are more accurate than autopsies and that autopsies are obsolete because they do not confer any marginal diagnostic advantage[2,3]

- Economic: increase in costs, other budget line items taking priority, lack of incentives[4,5]

- Legal: hospitals' concerns about potential legal action resulting from detection of diagnostic discrepancies, given that the clinical autopsy is a powerful tool for settling malpractice claims[3,5]

- Religious: prohibition by some religions[6]

- Cultural: conflicting beliefs and practices regarding treatment of the dead[5,6]

- Negative attitudes of doctors (including pathologists)[3,5, $7,8]$

- Discomfort about recommending autopsy to relatives (due to inexperience or lack of interpersonal skills) or considering it an administrative burden

- Fear of lawsuits if results contradict antemortem diagnosis

- Fear of being discredited professionally

- Frustration with infrequency of autopsy and long wait times for final reports
- Decreased autopsy quality, if pathologists find it difficult or distasteful, or if they prefer newer alternatives (virtopsy, ecopsy, partial autopsy, verbal autopsy, etc.)

- Fear of disease transmission via blood and body fluids

Shojania and Burton have argued that pathologists are increasingly preferring to spend their time on new and sophisticated (and more profitable) molecular diagnostic tests conducted on tissue biopsies of living patients rather than on autopsy, which has barely changed over the past century.[3] These authors identify two factors that explain diminishing interest in clinical autopsy: the incorrect belief that new technology has rendered autopsy obsolete, and doctors' general aversion to asking family members of the deceased for consent to perform autopsy. The decreased autopsy rate in the USA is partially due to lack of incentives to perform them: In 1971, the US Joint Commission on Accreditation of Healthcare Organizations eliminated the requirement for a minimum autopsy rate for hospital accreditation, and in 1986, Medicare stopped paying for autopsies.[3] In 2007, autopsies were performed on only $8 \%$ of deaths in the US.[9] From 1972 to 2007 , autopsy rates decreased from $16.9 \%$ to $4.3 \%$ in deaths caused by disease, in contrast to deaths caused by external factors, in which autopsies increased from $43.6 \%$ to $55.4 \%$. With so few autopsies performed, many conclusions on cause of death from serious illness or in patients aged $>65$ years are consequently based on diagnoses and tests performed before death, unconfirmed by autopsy.[9] The situation is similar elsewhere.[1,5,7,8] In Austria and the Scandinavian countries, clinical autopsy rates are between $15 \%$ and $20 \%$, lower than in Cuba.[10]

The purpose of this article is to reaffirm the importance of preserving the practice of autopsy and to present status and achievements related to autopsy in Cuba.

\section{WHY WE SHOULD PRESERVE THE PRACTICE OF AUTOPSY}

Importance Autopsy has always been highly valued because it provides evidence for continuous improvement of clinical diagnosis and assists in determining cause of death, which is important to ensure the quality of vital statistics. Bassat asserts that postmortem examinations are especially needed in low-income countries, where tools for antemortem clinical diagnosis are less available and cause-of-death data are limited.[1]

Many think that advances in antemortem diagnostic methods have devalued autopsies,[10] but despite such sophisticated techniques, the percentage of deaths in which antemortem diagnosis is contradicted by postmortem findings has not substantially decreased, as might be expected. In some cases these new diagnostic methods have led to incorrect diagnoses, due to doctors 'overreliance on their results. Plus, the new techniques entail a continuous learning curve as new procedures are incorporated into practice.[2,11,12]

Autopsy's utility is universal, not contextual. It is especially important in low- and middle-income countries lacking modern 
technology for diagnosis. One merit of the Cuban health system is that it has maintained provision of free, ethical and high quality autopsy services, available to all, with attendant social, welfare, professional and educational benefits.

Benefits of clinical autopsy The many benefits for patients, families, doctors (especially pathologists), medical students, health and academic institutions and society[13] include:

- information for clinicians, who can learn from their successful diagnoses and their own errors; $[3,7,12,13]$

- physician education for daily practice in various fields (e.g., through revealing pathological findings in advanced or rare diseases); $[3,7,8,12,13]$

- identification and explanation of emerging and reemerging diseases (e.g., HIVIAIDS, Legionnaires' disease, West Nile virus, Zika virus);[3,7,8,13]

- contribution to quality assurance of instruments and performance of antemortem diagnosis (clinical evaluation, imaging, lab analysis, anatomical pathology); $[8,13]$

- motivation for and source of scientific research and innovation; $[3,7,8,13]$

- greater accuracy of vital statistics;[3,7,13]

- greater accuracy of cause of death data for research;[3,7,12,13]

- improved postmarketing surveillance of side effects of medications, equipment and procedures; $[8,13]$

- identification of other factors of interest to family members, public health authorities and society; $[3,8,12,13]$ and

- provision of organs and tissues for transplants.[8,13]

There are some basic requirements for a quality autopsy. The Royal College of Pathologists of Australasia Autopsy Working Party provides criteria that can serve as a guide.[5] They include:

- sufficient numbers of pathologists with skills and interest in performing and studying autopsies and adequate time to provide high quality service;

- a properly trained support team with modern infrastructure, with sufficient laboratory support to perform timely, high-quality histological and other studies;

- timely reporting of autopsy results to clinicians for optimal utility in communication with families;

- accurate, timely, detailed and accessible final reporting;

- formal review of all autopsy results to compare with antemortem clinical diagnosis;

- recognition of the important role of autopsy in the hospital, with support of administrators, health officials, quality assurance committees, etc.;

- ongoing support from health authorities, recognizing autopsy's contributions to their work, to medical associations, to medical universities and to other groups of medical professionals and educators; and

- provision of autopsy information to the family and community to improve their understanding of their family members' diseases, increase trust in the health system and change the perception of autopsy as a violation of personal integrity.

Regardless, although autopsy is considered the gold standard for confirming or refuting clinical diagnosis, it is not foolproof. Some diseases and conditions are difficult or impossible to detect by pathological examination (e.g., cardiac arrhythmias and metabolic disturbances) and even pathologists can make mistakes.[12]
Medical imprecision and errors Medicine has always been venerated for its contributions promoting health and prolonging life, and the practice of medicine brings physicians much gratification, but such satisfaction can be overshadowed if they make a mistake, particularly if the mistake has fatal consequences. Chance of error in medical diagnosis or treatment were once accepted as inevitable,[13] and suspected errors would occasionally prompt autopsies to learn lessons for the benefit of future cases and to add to medical knowledge. Autopsy was, and still is, the most objective and exact way to determine cause of death.[13] Moreover, clinical-pathological discussions are important for evaluating and improving quality of hospital care. Without autopsies, physicians cannot learn from their errors, a sine qua non for improving medical care.

Gorovitz and Maclntyre have proposed a theory of medical fallibility, a view of medicine as a science of particulars. In other words, each particular doctor/patient interaction within a specific context and disease presentation is unique. Imprecisions or errors are unavoidable because of large variations in disease presentation, leading to erroneous interpretations and incorrect diagnoses.[14] Makary and Daniel calculate that medical error is the third leading cause of death in adults in the USA, but remains invisible in vital statistics because it is not listed as a category in the International Classification of Diseases.[15]

\section{ALTERNATIVES TO AUTOPSY}

Recently, various noninvasive or minimally invasive methods (generally more expensive) have been developed in response to decreased autopsy rates in some contexts due to its low acceptability.[13] Ideally, these methods should yield fairly similar results to conventional autopsy. Postmortem investigations with needle biopsy, endoscopy and radiology may be more readily accepted by family members, but are less precise than autopsy and require specialized resources. [3] Additionally, they may provide only partial information and may miss important information about contributing diseases.

Noninvasive methods Imaging methods such as MRI, computerized axial tomography (CAT) and ultrasound have also been proposed.[16,17] These methods offer advantages, mainly because they are noninvasive (known as virtual autopsy or virtopsy) and therefore, they are highly accepted in some places. Regardless, their high cost and dependence on sophisticated equipment and specially trained personnel are serious obstacles to widespread introduction in practice, particularly in low- and middle-income countries. $[1,18]$

Minimally invasive autopsy (MIA) can be used in addition to these imaging techniques or independently of them and is an important alternative to conventional autopsy. $[19,20]$ MIA includes a range of postmortem samples of major organs, using fine biopsy needles to obtain tissue fragments and fluid samples. Its advantages include rapidity, simplicity, safety and lack of disfigurement. Moreover, with MIA, samples can be examined for microorganisms, which is rarely possible with conventional autopsies due to high contamination risk from dissection. However, MIA still needs to be validated with respect to its results compared to complete autopsy, 
acceptability, feasibility, appropriateness and local requirements for application in different geographical, cultural and religious contexts.[1]

Results have recently been published from a study aimed at validating whether MIA could replace conventional autopsy for death by natural causes.[17] A CAT scan/MRI combination was the noninvasive method with the highest anatomical-clinical correlation for cause of death, i.e. $70 \%(95 \% \mathrm{Cl}$ $62.6 \%-76.4 \%$ ), higher than echopsy (based on ultrasound) and conventional radiography. MIA yielded better results than noninvasive autopsy. A CAT, CAT-angiography and biopsy combination had higher sensitivity for cause of death, $90.9 \%$ (95\% Cl 74.5\%-97.6\%), higher than thoracoscopy, laparoscopy and other invasive methods on their own. The authors concluded that minimally invasive autopsy involving biopsy is the best option.[17] However, more research is needed to establish it as a practical alternative to conventional autopsy.

Verbal autopsy In populations lacking vital statistics registries and medical death certificates, where autopsies are not possible, verbal autopsies have been recommended as a partial solution, providing a primary source of cause-of-death information. Verbal autopsies entail a standardized interview with the family of the deceased and an interpretation of the information obtained to infer the possible cause of death. This method provides only a limited understanding of the main causes of death, which is a serious obstacle for prioritization of effective health programs and subsequent evaluation of their effects.[21]

\section{AUTOPSY IN CUBA}

Cuba's health system is globally recognized for succeeding in providing free, universal, comprehensive health care in spite of limited resources and over half a century of US economic sanctions, achieving results similar to those of wealthier, more developed countries.[22-24] Autopsy performance is considered one of the strengths of Cuba's health system, despite resource constraints. $[2,8]$

Consent for autopsy in Cuba is always voluntary and must be obtained from family members or next of kin, after doctors and clinical staff explain reasons for its performance. The entire medical team is implicated in the process of obtaining autopsy consent, although direct responsibility for making requests falls to attending physicians in their interaction with family members. Although autopsy serves professional and institutional interests in medical care quality improvement, explicit informed consent from the family is required.

Accredited anatomical pathology departments are responsible for making sure the body is handled correctly (both technically and ethically). Family members and appropriate public health authorities must be notified of any previously undiagnosed communicable diseases (e.g., tuberculosis) detected. Family members have the right to be informed of the procedures carried out, as well as their results.[2]

Learning from autopsy is one of the most productive activities in anatomical pathology departments in Cuban hospitals.
Clinical anatomy sessions are held at least once a week for specialists, residents, interns and students to discuss recent deaths and present preliminary macroscopic anatomical findings. Every month, a clinical-pathological conference is held, in which a case study selected by the anatomical pathology department is presented and discussed with the whole medical team.[2,8]

When final autopsy reports are available, clinical files are reviewed again and discussed in a monthly meeting of the hospital mortality review committee, another very useful session for hospitals. Causes of death recorded on death certificates may be corrected at this time if they do not match autopsy findings, which helps improve the quality of vital statistics.[2]

Autopsy rates for hospital deaths in Cuba are nearly 60\%,[25] quite different than those reported above for other countries. Clinical autopsies are the responsibility of qualified specialists from anatomical pathology departments throughout the country, located in the main hospitals of all provinces, and accessible to family members of patients who die there.

The Sistema Automatizado de Registro y Control de Anatomía Patológica (an automated anatomical pathology registry, known as SARCAP) established in Cuba in 1985,[13] provides a database that currently holds information on 140,017 autopsies, as discussed in the recent 4th Congress of the Cuban Division of the International Academy of Pathology and the 14th Congress of the Cuban Society of Anatomical pathology in Havana (November 14-17, 2016). Cuba also has a solid statistical reporting system and analytic capacity in the National Statistics Division of the Ministry of Public Health (MINSAP), which receives information from all levels of the National Health System (SNS).[24] In 1992, a statistical information system for fatalities and autopsies was set up in the National Statistics Division.[26]

One of the authors of this article has reviewed Cuba's series of annual deaths from 1991 to 2014 (numbers and rates)[8] and found an overall autopsy rate of $36.4 \%$ during that period, and $34.9 \%$ if fetal autopsies were excluded (data updated to 2015 are shown in Table 1). The overall autopsy rate for hospital deaths between 1993 and 2015 was 55.4\%.[8]

The case of Cienfuegos provincial hospital The SNS'S organizational experience with public hospitals has not being disseminated as much as its work in primary care services. [27] The Dr. Gustavo Aldereguía Lima University General Hospital (HGAL) serves Cienfuegos Province (one of the smallest in Cuba, with a population of 401,575 in 2008). With 640 beds, HGAL is a referral hospital that provides secondary and tertiary care in clinical and surgical services including but not limited to, internal medicine, surgery, gynecology and obstetrics, and neonatology.[27-30]

Every year, some 1000 patients die in HGAL. Since its inauguration 37 years ago, HGAL's autopsy rates have almost always been in the $70 \%-80 \%$ range or higher. However, in the past three years, autopsy rates have declined slightly (Table 2), although still high compared to rates in other countries. Factors 


\section{Perspective}

Table 1: Autopsies in Cuba, 1991-2015

\begin{tabular}{|l|r|r|r|r|r|}
\hline Year & Deaths & Autopsies & Rate (\%) & $\begin{array}{r}\text { Autopsies } \\
\text { (nonfetal) }\end{array}$ & Rate (\%) \\
\hline 1991 & 71,709 & 28,672 & 40.0 & n/a & n/a \\
\hline 1992 & 75,457 & 28,667 & 38.0 & n/a & n/a \\
\hline 1993 & 78,531 & 30,840 & 39.3 & n/a & n/a \\
\hline 1994 & 78,648 & 30,216 & 38.4 & n/a & n/a \\
\hline 1995 & 77,937 & 30,651 & 39.3 & n/a & n/a \\
\hline 1996 & 79,662 & 33,165 & 41.6 & 30,645 & 38.5 \\
\hline 1997 & 77,316 & 31,241 & 40.4 & 28,307 & 36.6 \\
\hline 1998 & 77,565 & 29,803 & 38.4 & 26,741 & 34.5 \\
\hline 1999 & 79,499 & 31,312 & 39.4 & 28,146 & 35.4 \\
\hline 2000 & 76,463 & 32,437 & 42.4 & 29,468 & 38.5 \\
\hline 2001 & 79,395 & 33,472 & 42.2 & 30,723 & 38.7 \\
\hline 2002 & 73,883 & 31,416 & 42.5 & 28,558 & 38.7 \\
\hline 2003 & 78,434 & 31,871 & 40.6 & 29,258 & 37.3 \\
\hline 2004 & 81,103 & 29,272 & 36.1 & 26,786 & 33.0 \\
\hline 2005 & 84,823 & 29,571 & 34.9 & 27,233 & 32.1 \\
\hline 2006 & 80,827 & 27,096 & 33.5 & 24,925 & 30.8 \\
\hline 2007 & 81,922 & 28,293 & 34.5 & 25,954 & 31.7 \\
\hline 2008 & 86,611 & 28,263 & 32.6 & 25,792 & 29.8 \\
\hline 2009 & 86,941 & 27,904 & 32.1 & 25,338 & 29.1 \\
\hline 2010 & 91,059 & 27,007 & 29.7 & 24,836 & 27.3 \\
\hline 2011 & 87,040 & 28,641 & 32.9 & 26,083 & 30.0 \\
\hline 2012 & 89,368 & 30,410 & 34.0 & 28,294 & 31.7 \\
\hline 2013 & 92,270 & 29,989 & 32.5 & 27,694 & 30.0 \\
\hline 2014 & 96,328 & 28,989 & 30.1 & 27,038 & 28.1 \\
\hline 2015 & 99,694 & 31,761 & 31.9 & 29,750 & 29.9 \\
\hline Total & $2,062,485$ & 750,959 & 36.4 & 551,569 & 34.9 \\
\hline
\end{tabular}

n/a: not available

Source: National Health Statistics Department, Ministry of Public Health

Table 2: Autopsy rates in Cuban hospitals, 1996-2015

\begin{tabular}{|c|c|c|c|c|c|c|}
\hline \multirow[t]{2}{*}{ Year } & \multirow{2}{*}{$\begin{array}{c}\text { All } \\
\text { hospital } \\
\text { deaths }\end{array}$} & \multirow[t]{2}{*}{ Autopsies } & \multirow{2}{*}{$\begin{array}{c}\text { Rate } \\
(\%)\end{array}$} & \multicolumn{3}{|c|}{$\begin{array}{c}\text { Dr. Gustavo Aldereguía Lima } \\
\text { University General Hospital } \\
\text { (Cienfuegos, Cuba) }\end{array}$} \\
\hline & & & & Deaths & Autopsies & $\begin{array}{c}\text { Rate } \\
(\%)\end{array}$ \\
\hline 1996 & 34,788 & 20,574 & 59.1 & 1,198 & 1,001 & 83.5 \\
\hline 1997 & 33,367 & 19,658 & 58.9 & 1,092 & 859 & 78.7 \\
\hline 1998 & 33,342 & 18,540 & 55.6 & 1,179 & 925 & 78.5 \\
\hline 1999 & 34,353 & 19,517 & 56.8 & 1,242 & 953 & 76.7 \\
\hline 2000 & 32,705 & 19,966 & 61.0 & 1,198 & 932 & 77.8 \\
\hline 2001 & 34,063 & 21,137 & 62.1 & 1,123 & 959 & 85.4 \\
\hline 2002 & 31,591 & 19,443 & 61.5 & 1,045 & 921 & 88.1 \\
\hline 2003 & 33,322 & 20,319 & 61.0 & 1,082 & 911 & 84.2 \\
\hline 2004 & 33,488 & 18,701 & 55.8 & 1,041 & 880 & 84.5 \\
\hline 2005 & 35,039 & 18,788 & 53.6 & 1,118 & 942 & 84.3 \\
\hline 2006 & 33,256 & 17,204 & 51.7 & 1,058 & 860 & 81.3 \\
\hline 2007 & 33,746 & 18,859 & 55.9 & 1,109 & 928 & 83.7 \\
\hline 2008 & 34,390 & 18,741 & 54.5 & 1,072 & 832 & 77.6 \\
\hline 2009 & 3 & 18,177 & 53.4 & 1,042 & 842 & 80.8 \\
\hline 2010 & 35,384 & 18,576 & 52.5 & 1,162 & 902 & 77.6 \\
\hline 2011 & 35,218 & 18,765 & 53.3 & 1,193 & 906 & 75.9 \\
\hline 2012 & 35,275 & 19,266 & 54.6 & 1,186 & 1,001 & 84.4 \\
\hline 2013 & 35,904 & 18,813 & 52.4 & 1,185 & 822 & 69.4 \\
\hline 2014 & 36,612 & 17,606 & 48.1 & 1,193 & 783 & 65.6 \\
\hline 2015 & 37,795 & 18,543 & 49.1 & 1,322 & 902 & 68.2 \\
\hline Total & 687,689 & 381,193 & 55.4 & 22,840 & 18,061 & 79.1 \\
\hline
\end{tabular}

Source: National Statistics Division, Ministry of Public Health and Statistics Department, Dr. Gustavo Aldereguía Lima University General Hospital related to hospital renovations and upgrading of its anatomical pathology department have contributed to this decrease. Hospital administrators are aware of these results and have defined a recovery strategy and monitoring system. However, this phenomenon should be a reminder to health services managers nationally that the positive health indicators at our best hospitals would hardly be possible without autopsies, and that human and material resources for anatomical pathology services must be strengthened to maintain best health results.

Research on autopsy results at HGAL has been conducted to identify reasons for lack of correspondence in main cause of death between antemortem diagnosis and autopsy findings, to take advantage of lessons learned and continue improving quality of care.[31-34] Moreover, clinical anatomy sessions with macroscopic autopsy results are held weekly, and a clinical pathology conference is held monthly, in which a case study is presented and discussed.

Due to the systemic nature of Cuban public health-in which medical care, education and research (biomedical, clinical and epidemiologic) work hand in hand-it is recognized that the combination of clinical research and anatomical pathology plays an important role in Cuba's health achievements, [13,35] something that remains elusive in other areas of the world. [10]

\section{FINAL REMARKS}

Autopsy continues to be the gold standard for diagnosis of many diseases and injuries whose causes of death are expressed in anatomical damage and histological patterns. In Cuba, autopsy results provide further value in subsequent clinicalpathological discussions among pathologists and specialists in medical services of various hospitals, and autopsy information is integrated with data from patients' clinical histories.

High autopsy rates and quality standards in Cuba (because of availability of trained pathologists throughout the country) and the use of autopsy results for medical care, education, research, innovation and health administration provide a good rationale for including autopsy as one of the strengths of Cuba's SNS and an important guarantor of patient safety. Therefore it is periodically assessed by MINSAP with the systematic participation of various medical specialties in hospitals throughout Cuba.

The future of autopsy is in the hands of all involved and interested in its continued performance, the main beneficiaries of which are attending physicians, health care administrators, pathologists and society as a whole. Pathologists are largely responsible for obtaining the best results from autopsies and for promoting autopsy as the definitive study of patients and disease before each file is closed.

Although it is important for Cuba to make advances in diagnostics, based on exacting technology assessment criteria, addressing not only procedures' metric properties (sensitivity, specificity and predictive values) but also rigorous cost-benefit considerations, clinical autopsy still holds an important place in medical quality assurance and patient safety, especially in teaching hospitals. We welcome all efforts to increase autopsy rates and publish their results, so that death can continue to help life. 1 - 


\section{REFERENCES}

1. Bassat $Q$, Castillo P, Alonso PL, Ordi J, Menéndez C. Resuscitating the dying autopsy. PLoS Med [Internet]. 2016 Jan 12 [cited 2016 Aug 7];13(1):e1001927. Available from: http://jour nals. plos.org/plosmedicine/article?id=10.1371/ journal.pmed.1001927

2. Espinosa-Brito A, Viera-Yaniz J, Chávez-Troya $\mathrm{O}$, Nieto-Cabrera R. Death of the teaching autopsy. Autopsy is a success story in Cuba. Brit Med J. 2004 Jan 17;328(7432):166

3. Shojania KG, Burton EC. The vanishing nonforensic autopsy. N Engl J Med. 2008 Feb 28;358(9):873-5

4. Hasson J. Medical fallibility and the autopsy in the USA. J Eval Clin Pract. 1997 Aug;3(3):229-34.

5. Royal College of Pathologists of Australasia Autopsy Working Party. The decline of the hospital autopsy: a safety and quality issue for healthcare in Australia. Med J Aust. 2004 Mar 15;180(6):281-5.

6. Burton JL, Underwood J. Clinical, educational, and epidemiological value of autopsy. Lancet. 2007 Apr 28;369(9571):1471-80.

7. Hurtado de Mendoza-Amat J, Montero-González TJ, Ygualada-Correa I. Situación actual y perspectiva de la autopsia en Cuba. Rev Cubana Salud Pública [Internet]. 2013 Jan-Mar [cited 2013 Jan 30];39(1):135-47. Available from: http://scielo.sld.cu/pdf/rcsp/v39n1/spu12113.pdf. Spanish

8. Hurtado de Mendoza-Amat J. La autopsia como fortaleza del sistema de salud de Cuba. Rev Cubana Salud Pública [Internet]. 2016 [cited 2016 Apr 18] 42;2. Available from: http://www .revsaludpublica.sld.cu/index.php/spu/article/ view/714/590. Spanish.

9. Hoyert DL. The changing profile of autopsied deaths in the United States, 1972-2007. National Center for Health Statistics. NCHS Data Brief. 2011 Aug;(67):1-8.

10. van den Tweel JG, Wittekind C. The medical autopsy as quality assurance tool in clinical medicine: dreams and realities. Virchows Arch. 2016 Jan;468(1):75-81.

11. Goldman L, Sayson R, Robbins S, Cohn LH, Bettmann M, Weishberg M. The value of the autopsy in three medical eras. N Engl J Med. $1983 \mathrm{Apr}$ 28;308(17):1000-5.

12. Ayoub T, Chow J. The conventional autopsy in the modern medicine. J R Soc Med. 2008 Apr;101(4):177-81.

13. Hurtado de Mendoza Amat J. Autopsia. Garantía de calidad en la medicina [Internet]. 2nd ed. Havana: Editorial Ciencias Médicas; 2014 [cited 2016 Apr 18]. 226 p. Available from: http://www .bvs.sld.cu/libros/autopsia_garantia_2daedicion/ indice_p.htm. Spanish.

14. Gorowitz S, Maclntyre A. Toward a theory of medical fallibility. In: Engelhart HT, Callahan D, editors. Science, Ethics and Medicine. New York: Hastings Center; 1976. p. 248-74.

15. Makary MA, Daniel M. Medical error-the third leading cause of death in the US. Brit Med J. 2016 May 3;353:i2139.
16. Fariña $J$, Millana $C$, Fernández-Aceñero $M J$ Furió V, Aragoncillo P, Martín VG, et al. UItrasonographic autopsy (echopsy): a new autopsy technique. Virchows Arch. 2002 Jun;440(6):635-9.

17. Blokker BM, Wagensveld IM, Weustink AC, Oosterhuis JW, Hunink MG. Non-invasive or minimally invasive autopsy compared to conventional autopsy of suspected natural deaths in adults: a systematic review. Eur Radiol. 2016 Apr;26(4):1159-79.

18. Bolliger SA, Thali MJ, Ross S, Buck U, Naether $S$, Vock P. Virtual autopsy using imaging: bridging radiologic and forensic sciences. A review of the Virtopsy and similar projects. Eur Radiol. 2008 Feb;18(2):273-82.

19. Weustink AC, Hunink MG, van Dijke CF, Renken NS, Krestin GP, Oosterhuis JW. Minimally invasive autopsy: an alternative to conventional autopsy? Radiology. 2009 Mar;250(3):897-904.

20. Whitby E. Minimally invasive autopsy. Lancet. 2009 Aug 8;374(9688):432-3.

21. Soleman N, Chandramohan D, Shibuya K. Verbal autopsy: current practices and challenges. Bull World Health Org. 2006 Mar;84(3):239-45.

22. Lamrani S. Cuba's health care system: a model for the world. HuffPost Live [Internet]. 2014 [cited 2014 Oct 8]; [about 5 screens]. Available from: http://www.huffingtonpost.com/salim-lamrani/ cubas-health-care-system-_b_5649968.html

23. Spiegel J, Yassi A. Lessons from the margins of globalization: appreciating the Cuban health paradox. J Public Health Policy. 2004;25(1):85-110.

24. Keck CW, Reed GA. The curious case of Cuba. Am J Public Health. 2012 Aug;102(8):e13-22.

25. Hurtado de Mendoza Amat J, Álvarez Santana R. Situación de la autopsia en Cuba y el mundo. La necesidad de su mejor empleo. Patología. 2008;46(1):3-8. Spanish.

26. National Health Statistics and Medical Records Division (CU). Anuario Estadístico de Salud 2015. Havana: Ministry of Public Health (CU); 2016. 208 p. Spanish.

27. De Vos $P$, Ordúñez-García $P$, Santos-Peña $M$, Van der Stuyft P. Public hospital management in times of crisis: lessons learned from Cienfuegos, Cuba (1996-2008). Health Policy. 2010 Jun;96(1):64-71.

28. Hospital Universitario Dr. Gustavo Aldereguía Lima. Anuario Estadístico [Internet]. Cienfuegos: Hospital Universitario Dr. Gustavo Aldereguía Lima; 2015 [cited 2016 Apr 20]. Available from: http://www.gal.sld.cu/. Spanish.

29. Espinosa-Brito AD. La contribución del Hospital Dr. Gustavo Aldereguía Lima a la educación médica superior en Cienfuegos, 1979-2016. Medisur [Internet]. 2016 Apr [cited 2016 Apr 28];14(2):118-32. Available from: http://medi sur.sld.cu/index.php/medisur/article/view/3296. Spanish

30. Navarro-Machado VR, Falcón-Hernández A, Espinosa-Brito A, Romero-Cabrera AJ. A scientific and technological innovation system in a Cuban hospital (2000-2014). MEDICC Rev [Internet].
2016 Jan-Apr [cited 2016 Apr 30];18(1-2):3440. Available from: http://medicc.org/medicc review $/$ index. php? issue $=38 \& i d=518 \& a=v a$

31. Espinosa AD, Álvarez Li FC, Borges Rodríguez E, Quintana Pérez S, Fernández Turner M. Estudio clínico-patológico de 460 fallecidos con Infarto Miocárdico Agudo. Informe de dos series (1985-1987 y 1991-1993). Clín Cardiovasc (España). 2000;35:449-61.

32. Fernández Turner $M$, Sotelo Suárez I, Borroto Lecuna S, Figueiras Ramos B, Corona Martínez LA. Correlación clínico-patológica en pacientes fallecidos con diagnóstico clínico o anatomopatológico de enfermedad cerebrovascular durante los años 1997 al 2001. Rev Cubana Med [Internet]. 2003 Sep-Oct [cited 2016 May 5];42(5). Available from: http://scielo .sld.cu/scielo.php?script=sci_arttext\&pid=S0034 $-75232003000500005 \&$ lng $=$ es \&nrm=iso\&tlng= es. Spanish.

33. Espinosa-Brito AD. Mortalidad por hipertensión arterial. Tras la huella del "asesino silente". Rev Finlay [Internet]. 2012 Mar [cited 2016 Jul 4];2(1):50-65. Available from: http://www.rev finlay.sld.cu/index.php/finlay/article/view/100. Spanish.

34. Espinosa-Brito AD, Álvarez-Li FC, Ordúñez-García PO, Espinosa-Roca AA, Bermúdez-López JM, Viera-Yaniz J. La autopsia como "prueba de oro" en la evaluación de la calidad brindada a los fallecidos hospitalarios. El caso del Infarto Agudo de Miocardio. Infodir [Internet]. 2009 [cited 2010 Apr 10];(8). Available from: http://bvs.sld.cu/ revistas/infd/n809/infd1209.htm. Spanish.

35. Santos Peña MA, Rocha Hernández JF. La calidad y seguridad del paciente. Un derecho en la salud pública cubana. Boletín Informativo-CIESS [Internet]. 2016 [cited 2016 Apr 22];14. Available from: http://boletin.ciess.org/pdf/La-Calidad-y -Seguri.pdf. Spanish.

\section{THE AUTHORS}

Alfredo D. Espinosa-Brito (Corresponding author: alfredo espinosa@infomed.sld.cu), internist with a doctorate in medical sciences. Distinguished professor and senior researcher, Dr. Gustavo Aldereguía Lima University General Hospital, Cienfuegos, Cuba.

José Hurtado de Mendoza-Amat, anatomical pathologist with a doctorate in medical sciences and an advanced doctorate. Full professor and senior researcher, Hermanos Ameijeiras Clinical-Surgical Teaching Hospital, Havana, Cuba.

Submitted: September 19, 2016 Approved for publication: December 7, 2016 Disclosures: None 